\title{
Detecting Ecosystem Performance Anomalies for Land Management in the Upper Colorado River Basin Using Satellite Observations, Climate Data, and Ecosystem Models
}

\author{
Yingxin Gu ${ }^{1} *$ and Bruce K. Wylie ${ }^{2}$
}

1 ASRC Research \& Technology Solutions, Contractor to US Geological Survey Earth Resources Observation and Science Center, 47914 252nd Street, Sioux Falls, SD 57198, USA

2 US Geological Survey Earth Resources Observation and Science Center, 47914 252nd Street, Sioux Falls, SD 57198, USA; E-Mail: wylie@usgs.gov

* Author to whom correspondence should be addressed; E-Mail: ygu @usgs.gov; Tel.: +1-605-594-6576; Fax: +1-605-594-6529.

Received: 26 June 2010; in revised form: 22 July 2010 / Accepted: 28 July 2010 / Published: 29 July 2010

Abstract: This study identifies areas with ecosystem performance anomalies (EPA) within the Upper Colorado River Basin (UCRB) during 2005-2007 using satellite observations, climate data, and ecosystem models. The final EPA maps with 250-m spatial resolution were categorized as normal performance, underperformance, and overperformance (observed performance relative to weather-based predictions) at the $90 \%$ level of confidence. The EPA maps were validated using "percentage of bare soil" ground observations. The validation results at locations with comparable site potential showed that regions identified as persistently underperforming (overperforming) tended to have a higher (lower) percentage of bare soil, suggesting that our preliminary EPA maps are reliable and agree with ground-based observations. The 3-year (2005-2007) persistent EPA map from this study provides the first quantitative evaluation of ecosystem performance anomalies within the UCRB and will help the Bureau of Land Management (BLM) identify potentially degraded lands. Results from this study can be used as a prototype by BLM and other land managers for making optimal land management decisions.

Keywords: satellite remote sensing; MODIS NDVI; ecosystem performance; ecosystem performance anomalies; ecosystem models; climate data; land management 


\section{Introduction}

Ecosystem performance (EP) (i.e., a surrogate approaching ecosystem productivity) provides important information to decision makers for land management. Recently, satellite remote sensing has become an essential tool for measuring and monitoring large-area ecosystem performance because of its wide coverage and high spatial and temporal resolutions [1,2]. The growing season integrated Normalized Difference Vegetation Index (NDVI) derived from satellite observations is used as a proxy for vegetation dynamics and ecosystem performance [3-5]. Ecosystem performance is usually affected by site condition (e.g., drainage, elevation, slope and aspect, soils, and surface geology) [6-9], climate changes (e.g., precipitation and surface temperature) [10-14], natural disturbances (e.g., wildfires and floods) [12], and anthropogenic effects (e.g., heavy grazing) [15-16]. Interpreting ecosystem performance variation or ecological disturbance is complex because of the influences of weather, site potential, natural disasters and anthropogenic effects [17].

For moisture-limited rangelands, the interannual variation in vegetation productivity is significantly related to the local weather conditions, management practices, and disturbances. Wylie et al. [1] developed an approach that separates weather- and nonweather-related annual ecosystem performance (e.g., growing season NDVI) variations using satellite-derived NDVI data, weather data, site potential, and ecological models. This approach allows ecologists and land managers to easily interpret and identify nonweather-related ecosystem performance anomalies or ecological disturbance (such as wildfires or heavy grazing). This method also provides historical trend mapping in both weather- and nonweather-related EP variations, which helps guide the best management practices. Here, we define the expected ecosystem performance (EEP) as the expected growing season NDVI (GSN) in a particular year (i.e., given the weather conditions of that year and in the absence of disturbance). The EEP accounts for variations in productivity based on weather conditions; that is, favorable weather years will have higher EEP than those with unfavorable conditions (e.g., too hot or too cold, too wet or too dry). The ecosystem performance anomaly (EPA) for a year was derived based on the difference between the actual EP and the weather-based expected EP at a 90\% level of confidence. Natural disasters (e.g., wildfires, floods, windstorms) and anthropogenic effects (e.g., heavy grazing) usually induce significant EPA. A persistent EPA is defined as an EPA that is underperforming or overperforming for multiple years ( $>2$ years in this study).

The main objective of this study is to identify and quantify areas with long-term persistent EPA within the Upper Colorado River Basin (UCRB) based on satellite observations, climate data, and ecosystem models. Our initial study time period is 2005-2007, which will provide a 3-year persistent EPA map within the UCRB to the Bureau of Land Management (BLM) and other land managers as a prototype for making optimal land management decisions. Four vegetation cover types (grassland, big sagebrush, pinyon juniper, and salt scrub) were selected from the study area for building EP models. In this paper, we focus on investigating and evaluating the EPA results from the big sagebrush vegetation cover as a prototype for this study. Rule-based piecewise regression modeling methods were applied to predict the expected ecosystem performance [18-22]. The derived EPA maps were categorized as normal performance, underperformance, and overperformance (observed performance relative to weather-based predictions) at the $90 \%$ level of confidence. EPA maps from multiple years are used to identify persistent negative anomalies and trends of anomalies (i.e., is ecosystem underperformance 
becoming more severe with time?), which are typically diagnosed as degraded or degrading rangelands. These preliminary EPA maps are validated using "percentage of bare soil" data (an important driver of range conditions) obtained from the LANDFIRE field database [23].

\section{Study Area}

The study area focuses on the Upper Colorado River Basin, which covers parts of Wyoming, Utah, Colorado, Arizona, and New Mexico (Figure 1). A significant portion of the UCRB is managed by the BLM and the Bureau of Reclamation. More than $50 \%$ of the UCRB is covered by scrub and shrub land (e.g., pinion juniper, big sagebrush, and salt scrub). More than $20 \%$ of this region is covered by evergreen forest, and approximately $10 \%$ is grassland. Substantial portions of the UCRB are arid or semiarid systems where vegetation production is constrained by moisture availability. The land cover types [24] and the study area (within the blue outline) are shown in Figure 1.

Figure 1. Study area and land cover type map.

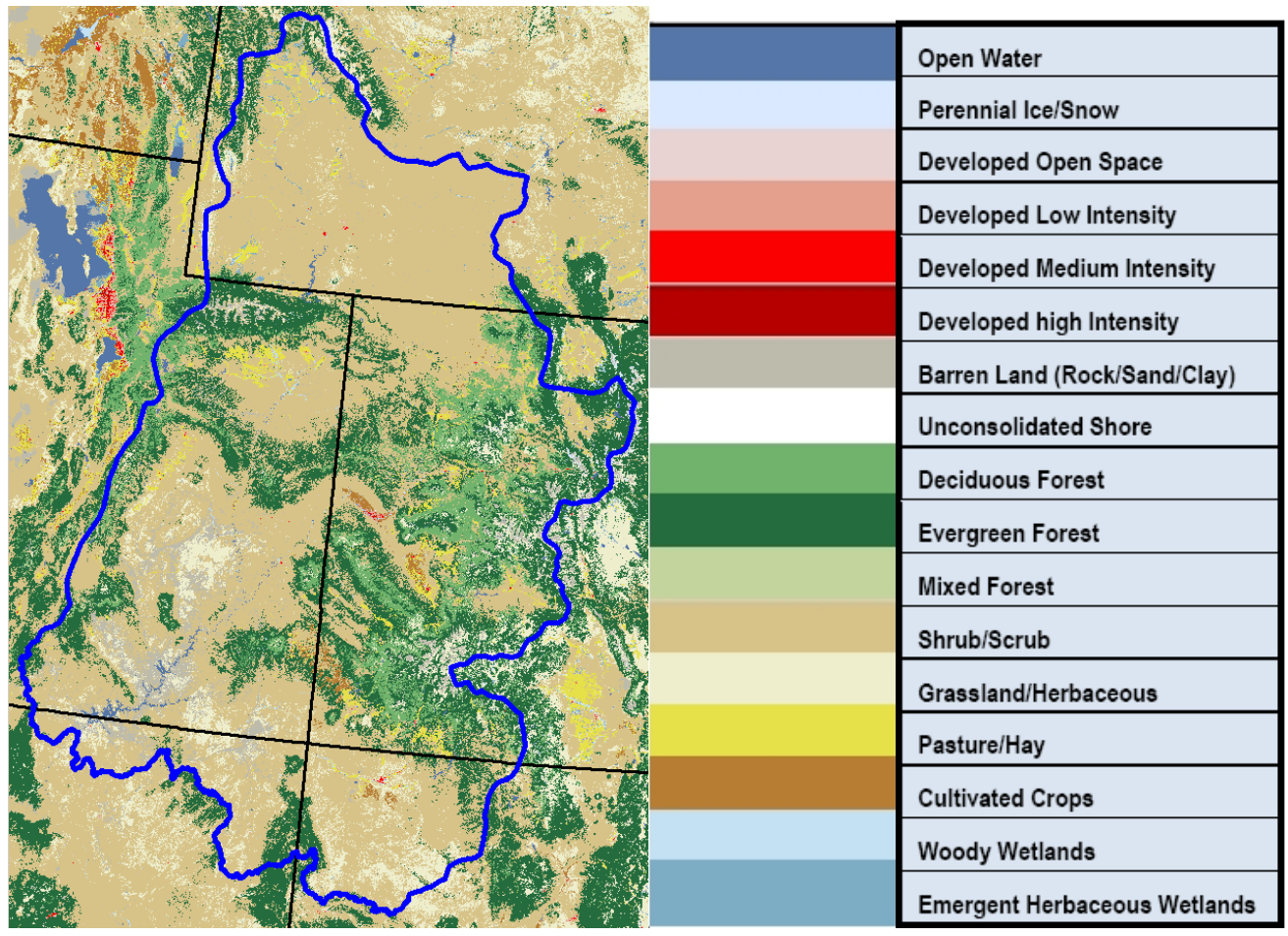

\section{Methodology and Data}

Our methodology was based on a previous successful ecosystem performance study [1] and is summarized in a flowchart (Figure 2). 
Figure 2. Flowchart for mapping ecosystem performance anomalies for land management using satellite observations, climate data, and ecological models.

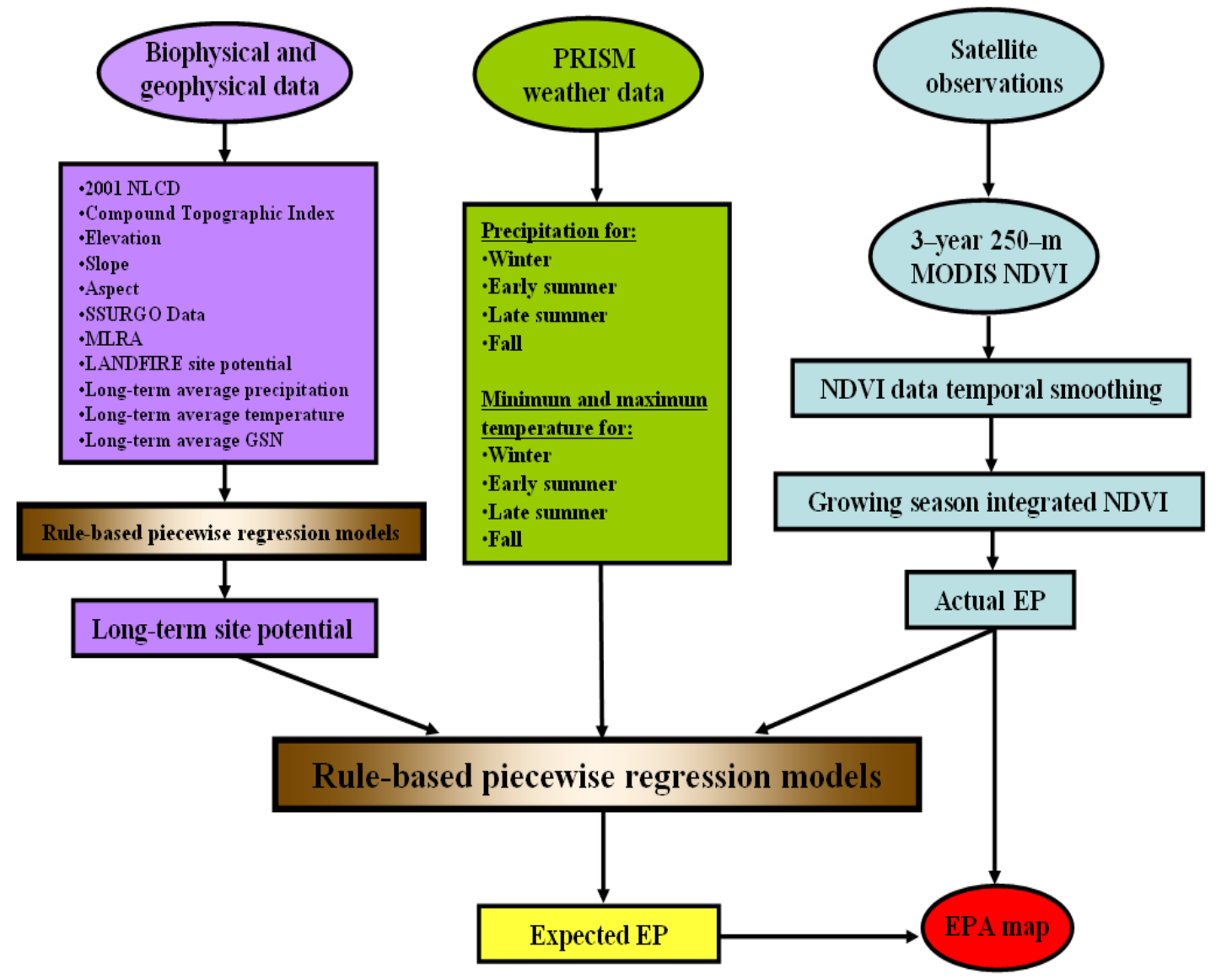

The EPA calculation, evaluation, and validation involved the following six steps:

1. Calculate the actual ecosystem performance for 2005-2007 using satellite-derived GSN from temporally smoothed 7-day 250-m eMODIS (expedited Moderate Resolution Imaging Spectroradiometer) NDVI [25-27].

2. Estimate ecosystem performance site potential for the UCRB using 3-year (2005-2007) averaged GSN, 20-year (1971-2000) climate data, and site condition data (e.g., elevation and topographic conditions, Soil Survey Geographic (SSURGO) total site production data) $[1,5,8,28]$.

3. Compute the yearly expected EP (2005-2007) for the UCRB using EP site potential, weather data, and rule-based piecewise regression modeling methods.

4. Determine ecosystem performance anomalies (the difference between the actual EP and the expected EP) for 2005-2007. The final EPA maps are categorized as overperformance, normal performance, and underperformance according to the $90 \%$ level of confidence interval.

5. Map areas that have a 3-year persistent negative EPA for the UCRB.

6. Evaluate and validate the 3-year EPA maps using ground observations (i.e., percentage of bare soil obtained from multiple research projects).

The USGS 30-m LANDFIRE Existing Vegetation Type data [29] was used to identify big sagebrush within the UCRB. 
The site potential map was developed at a $250-\mathrm{m}$ resolution to account for the important effects of elevation, slope, aspect [8,28], and growing season length. Rule-based piecewise regression modeling methods (using Cubist software [30]) were applied to estimate site potential (i.e., long-term rangeland productivity). Data used for training rule-based piecewise regression modeling for calculating long-term site potential (Figure 2) included total range production derived from the U.S. Department of Agriculture (USDA) Natural Resources Conservation Services (NRCS) SSURGO Database; USGS 30m compound topographic index (CTI) and digital elevation model (DEM); LANDFIRE environmental site potential data derived from USGS national LANDFIRE project [29]; Major Land Resource Areas (MLRA) data obtained from the USDA NRCS; north and south aspect and slope maps calculated from the USGS DEM map; long-term (1971-2000) averaged precipitation, maximum temperature, and minimum temperature derived from the PRISM (Parameter-elevation Regressions on Independent Slopes Model) database with 4-km spatial resolution (PRISM Climate Group, Oregon State University, http://www.prismclimate.org); and 3-year averaged GSN calculated from 2005-2007 eMODIS NDVI data. The 4-km spatial resolution PRISM data and the 30-m data (e.g., CTI, DEM) were resampled to 250-m resolution using bilinear interpolation (downscaling) or spatial averaging (upscaling) to match the 250-m eMODIS NDVI data.

The expected EP was calculated using a piecewise regression model based on the site potential and yearly seasonal climate variables. Data used for training rule-based piecewise regression models to calculate the expected EP (Figure 2) were 2004-2007 PRISM climate datasets (precipitation and temperature) for four seasons (Winter, November-February; Spring, March; Summer, April-June; Fall, July-October); long-term ecosystem site potential data; and 2005-2007 GSN data obtained from the weekly 250-m eMODIS NDVI time-series data.

\section{Results and Discussion}

\subsection{Ecosystem Performance Site Potential, Expected Ecosystem Performance, and Actual EP Maps}

Site potential represents the long-term EP that averages out climatic variations but accounts for spatial variation in long-term EP associated with site conditions such as drainage, elevation, slope and aspect [8,28], soils, domain clusters (with similar topographic and climate condition) [9], and surface geology. Site potential does not include disturbance effects (e.g., wildfires, floods, and overgrazing) and will generally reflect moisture gradients and temperature gradients in the UCRB. Highly productive sites will have higher ecosystem performance measures than sites with poorer soils, steeper slopes, or other conditions not conducive to vegetation growth.

Figure $3 \mathrm{a}$ is the site potential map for big sagebrush in the UCRB across multiple years. Different soil, topography, and climate conditions produce different site potentials (i.e., rangeland productivities) for big sagebrush as shown in Figure 3a. The northern part of the study area (southwestern part of Wyoming in brown) has a very low site potential (rangeland productivity) because of the unfavorable vegetation growth condition (e.g., soil type, high elevation, and aspect). On the other hand, a very high rangeland productivity region is present in Colorado (green-blue region) because of favorable site conditions (e.g., soil, topography). 
Figure 3. Examples of site potential map, EEP map, and the actual EP map for big sagebrush in the UCRB. (a) Modeled big sagebrush site potential map; (b) 2006 EEP map for big sagebrush; (c) 2006 actual EP map.

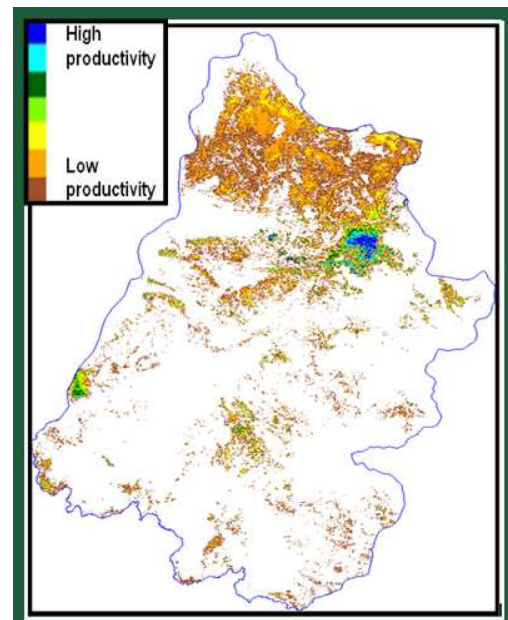

(a). Site potential

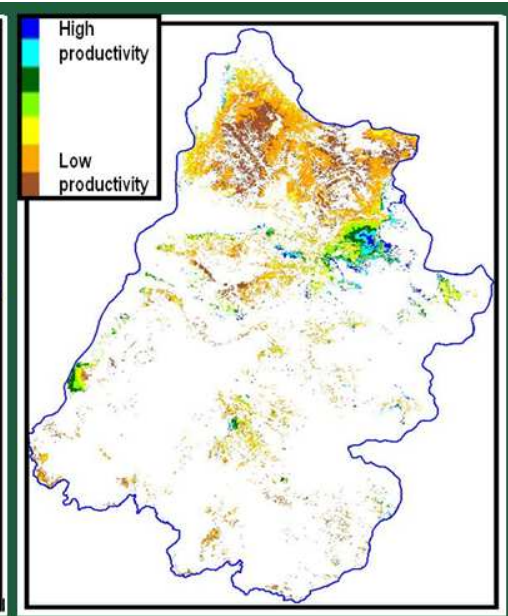

(b). Expected ecosystem performance (2006)

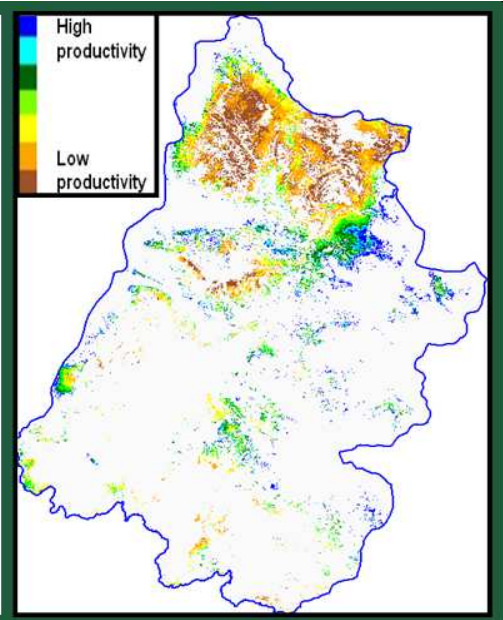

(c). Actual ecosystem performance (2006)

Figure 3b,c depicts the weather-based EP and the actual EP maps for 2006 for big sagebrush in the study area. We found that many parts of the study area had higher productivity in 2006 than the normal site productivities (i.e., site potential) in both the EEP map and the actual EP map. Desirable weather conditions during 2006 (e.g., suitable temperature and humidity for vegetation) led to high production.

To illustrate the relationship between the EEP and the actual EP, the scatterplot between EEP and the actual EP for those pixels randomly selected from the big sagebrush area within the UCRB for 2005-2007 is shown in Figure 4. The regression line in Figure 4 is used to (1) determine the $90 \%$ confidence intervals, which helps determine the anomaly, and (2) correct for minor model biases (i.e., systematic error of the model). We assume that most of the model error lies within the confidence intervals and that the variation of the residuals beyond the confidence intervals represents ecosystem performance anomaly information. In Figure 4, green points represent overperformance (areas are more productive than expected from weather) and are greater than the $90 \%$ confidence limit above the regression line; red points represent underperformance (areas are less productive than expected from weather) and are greater than the $90 \%$ confidence limit below the regression line. 
Figure 4. Expected ecosystem performance compared with the actual ecosystem performance for 2005-2007. Pixels were randomly selected from big sagebrush areas in the UCRB. Green points represent overperformance and are greater than the $90 \%$ confidence limit above the regression line. Red points represent underperformance and are greater than the $90 \%$ confidence limit below the regression line.

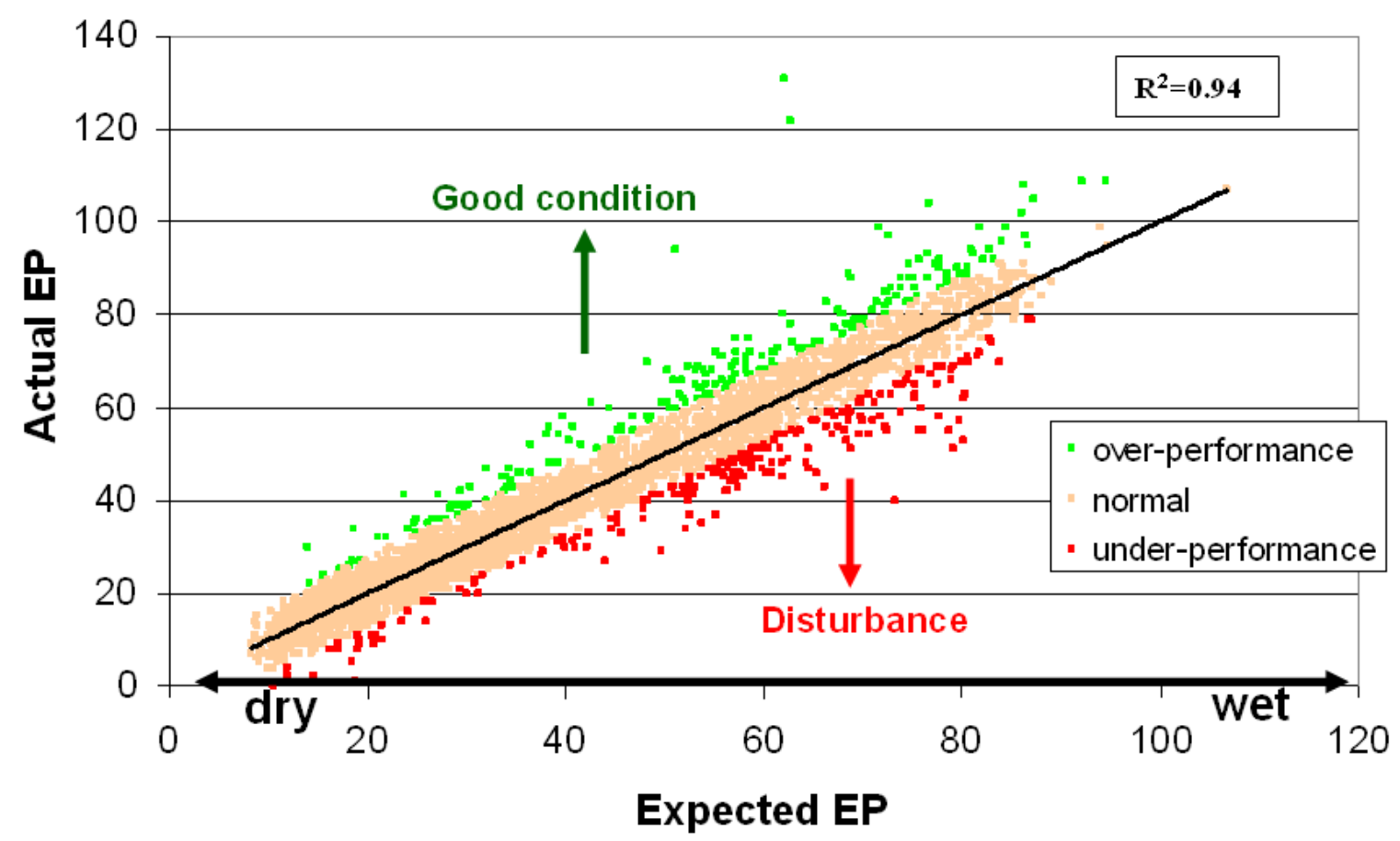

\subsection{Ecosystem Performance Anomaly Maps and Persistent EPA Maps}

Annual ecosystem performance anomaly maps were computed using the difference between EP and $\mathrm{EEP}_{\mathrm{c}} . \mathrm{EEP}_{\mathrm{c}}$ is the bias-corrected EEP, which is adjusted by the regression coefficients to account for any minor model biases for each year. Figure 5 shows the 2005-2007 EPA maps for big sagebrush in the UCRB. Yellow-green areas in Figure 5 represent overperformance and are greater than the 90\% confidence limit above the regression line. Red-pink areas represent underperformance and are greater than the $90 \%$ confidence limit below the regression line. The underperforming and overperforming patterns of each year are clearly shown in Figure 5. These annual EPA maps can be used to dynamically monitor and assess the rangeland conditions within the UCRB.

Figure 6 shows the 3-year (2005-2007) ecosystem performance anomaly map for big sagebrush. Areas identified as the 3-year persistent underperformance for big sagebrush within the UCRB (dark red in Figure 6) are mainly located in the southwestern part of Wyoming and the northwestern part of Colorado. This persistent EPA map will be used by BLM or other land managers to identify potentially degraded rangelands. 
Figure 5. Ecosystem performance anomaly maps for big sagebrush areas in the UCRB. Yellow-green areas represent overperformance and are greater than the $90 \%$ confidence limit above the regression line. Red-pink areas represent underperformance and are greater than the $90 \%$ confidence limit below the regression line.

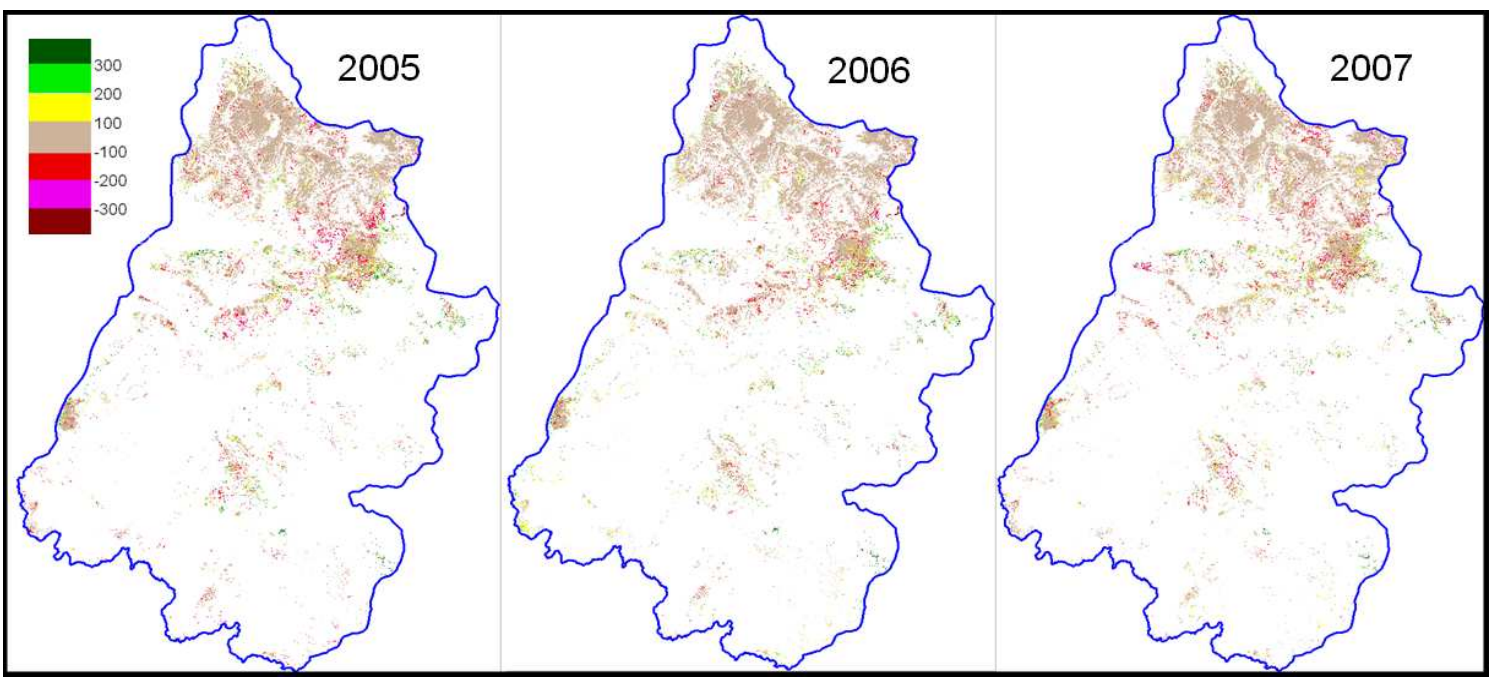

Figure 6. 3-year (2005-2007) ecosystem performance anomaly map for big sagebrush in the UCRB.

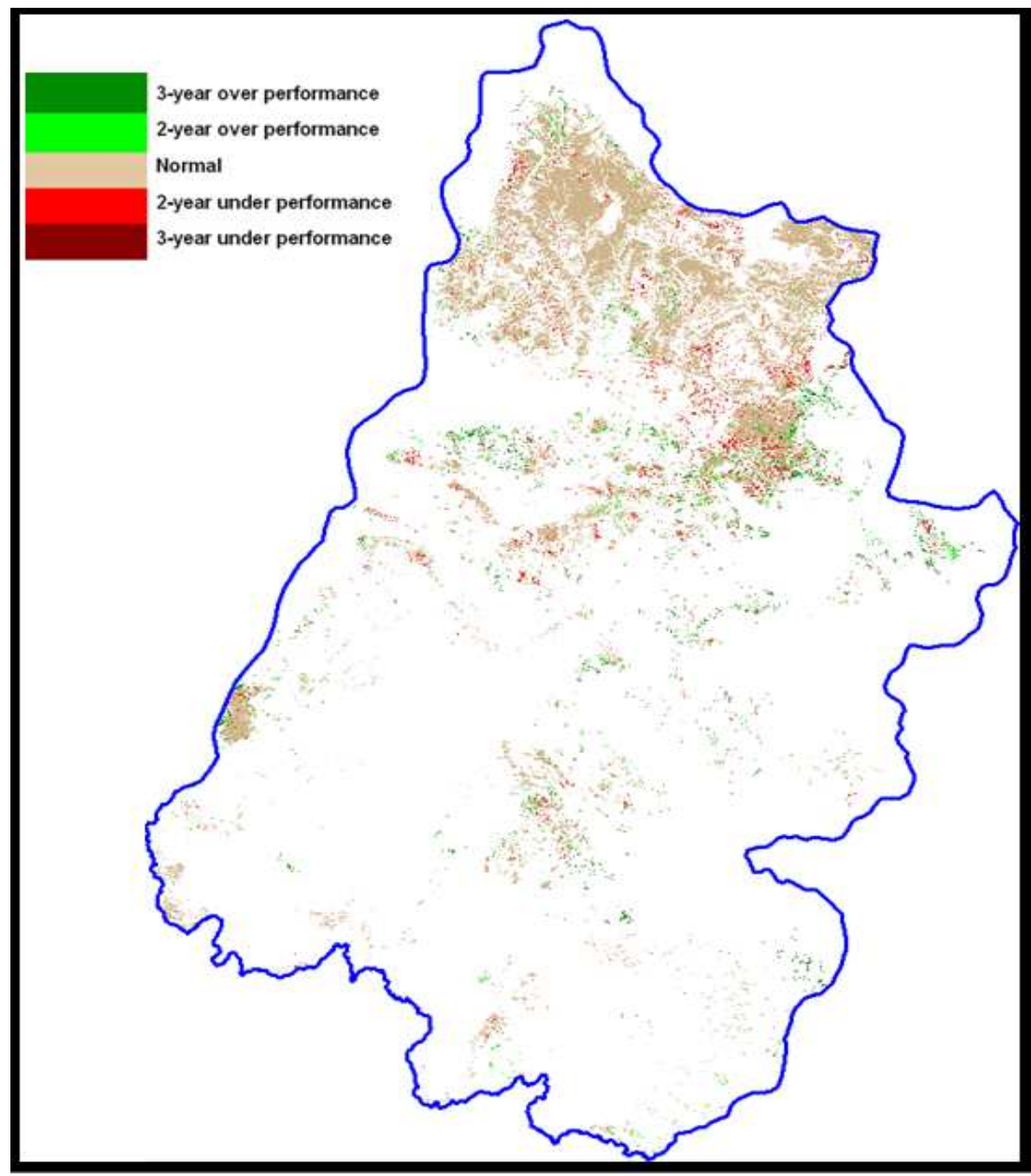




\subsection{EPA Map Validation and Applications}

Our EPA maps were validated using "percentage of bare soil" ground observations from a selected subset of the LANDFIRE field database, enabling us to relate anomalies to range conditions. A regression line is established for the normal performing pixels to establish a general relationship between site potential and percentage of bare ground (Figure 7). The validation results for big sagebrush at comparable site potential show that regions identified as persistently underperforming (pink) tended to have a lower range condition (higher percentage of bare ground) than normally expected from site potential; regions identified as overperforming (green) tended to have a higher range condition (lower percentage of bare ground). These results demonstrate that our EPA maps agree with ground-based observations (percentage of bare ground is an important driver of range condition) and provide reliable information for making land management decisions (e.g., grazing control).

Figure 7. Ecosystem performance anomaly (EPA) validation for big sage in the UCRB using "percentage of bare soil" ground observations from multiple research projects which represented smaller footprints than $250 \mathrm{~m}$. Regions identified as persistently underperforming (pink) tended to have a higher percentage of bare soil, and regions identified as overperforming (green) tended to have a lower percentage of bare soil. The regression is based only on observations within the confidence interval (normal) of Figure 4.

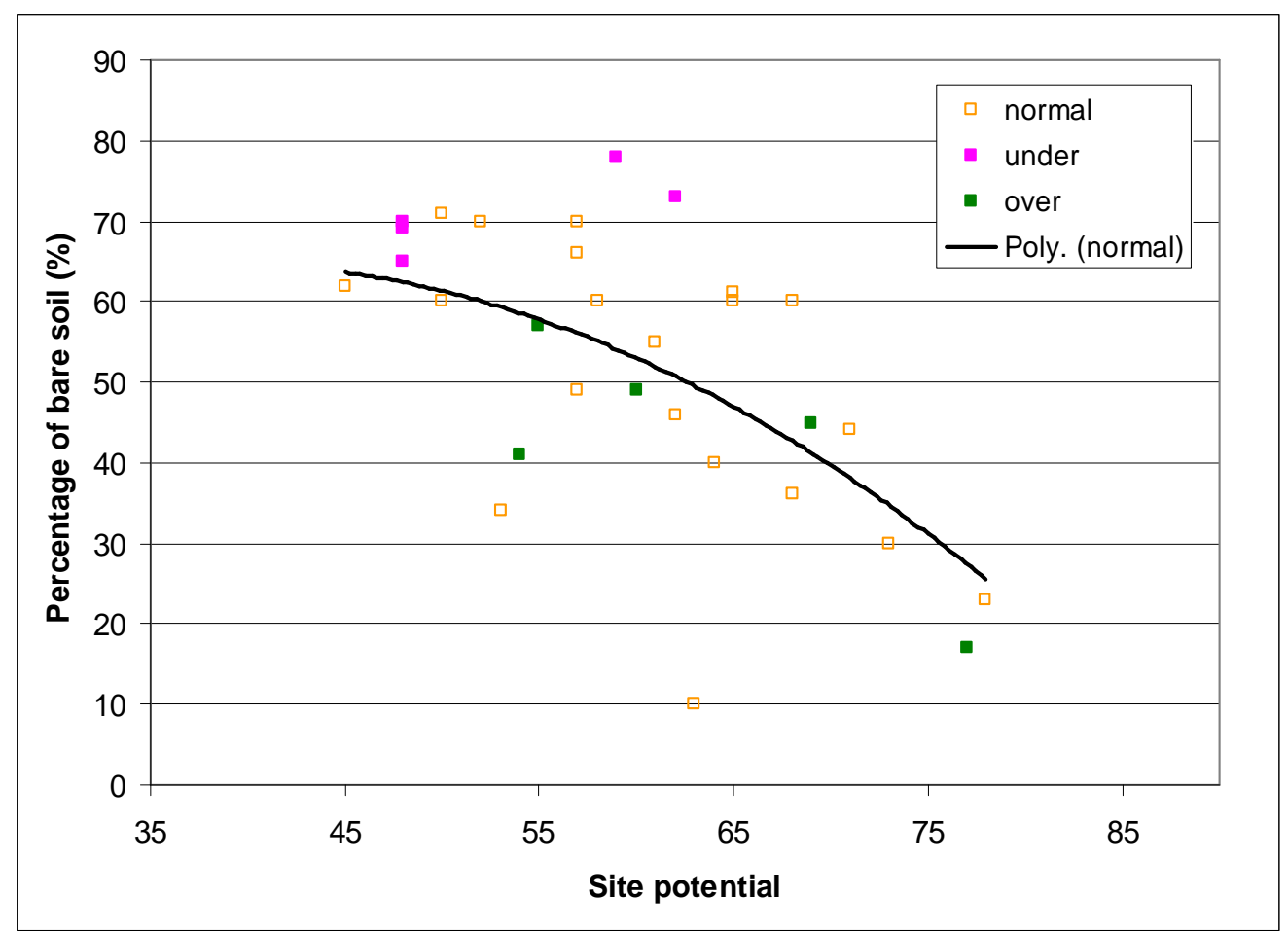

The validated 3-year persistent EPA map from this study will provide the first quantitative evaluation of ecosystem performance anomalies within the UCRB during 2005-2007 using satellite observations, climate data, and ecosystem models. These EP and EPA maps will be posted on the USGS Earth Resources Observation and Science (EROS) Center Land Cover Application (LCA) Web page for public access. BLM and other land managers plan to use these maps to make optimal land 
management decisions and to minimize economic and ecological losses associated with degraded rangelands. The EP and EPA maps described in this study can also be used for other applications related to land surface monitoring and assessment (e.g., drought assessment, rangeland monitoring, and assessments of ecological system and land cover changes).

\section{Conclusions and Future Work}

The first 3-year (2005-2007) persistent EPA map within the Upper Colorado River Basin was generated based on the satellite observations, climate data, and ecosystem models in this initial investigation. Areas in this 3-year EPA map were categorized as normal performance, underperformance, and overperformance. The EPA map was validated using "percentage of bare soil" ground observations. The validation results at comparable site potential showed that regions identified as persistently underperforming tended to have a lower range condition (a higher percentage of bare ground) than normally expected from site potential, and regions identified as overperforming tended to have a higher range condition (a lower percentage of bare ground) than the normal condition. The validation results suggest that our preliminary EPA maps agree with ground-based observations and will provide reliable information to BLM and other land managers for making optimal land management decisions.

Future work for this study includes generating 10-year (2001-2010) EPA maps within the UCRB using 10-year satellite observations, climate data, and ecosystem models, and identifying long-term (i.e., 10-year) persistent EPA areas and trends as well as weather-based variations in vegetation production. All these products will place this study in a historical and future climate context within the UCRB. Investigations of ecosystem performance anomalies for other vegetation cover types

(e.g., black sagebrush, mixed desert shrub) and field data collections (e.g., total range production, presence of species and soil crust) for further evaluation and validation of EPA maps are also planned for the future.

\section{Acknowledgements}

This work was performed under USGS contract 08HQCN0007 and funded by the USGS Land Remote Sensing Program, Climate Effects Network, and the Bureau of Land Management. The authors thank Norman Bliss for processing and providing SSURGO total range production data. The authors thank Norman Bliss, Bhaskar Ramachandran, Thomas Adamson, and two anonymous reviewers for their valuable suggestions and comments. Any use of trade, product, or firm names is for descriptive purposes only and does not imply endorsement by the US Government.

\section{References}

1. Wylie, B.K.; Zhang, L.; Bliss, N.B.; Ji, L.; Tieszen, L.L.; Jolly, W.M. Integrating modelling and remote sensing to identify ecosystem performance anomalies in the boreal forest, Yukon River Basin, Alaska. Int. J. Dig. Earth 2008, 1, 196-220. 
2. Zhang, L.; Wylie, B.K.; Ji, L.; Gilmanov, T.G.; Tieszen, L.L. Climate-driven interannual variability in net ecosystem exchange in the northern Great Plains grasslands. Rangel. Ecol. Manag. 2010, 63, 40-50.

3. Breshears, D.D.; Cobb, N.S.; Rich, P.M.; Price, K.P.; Allen, C.D.; Balice, R.G.; Romme, W.H.; Kastens, J.H.; Floyd, M.L.; Belnap, J.; Anderson, J.J.; Myers, O.B.; Meyer, C.W. Regional vegetation die-off in response to global-change-type drought. Proc. Nat. Acad. Sci. USA 2005, $102,15144-15148$.

4. Jia, G.J.; Epstein, H.E.; Walker, D.A. Spatial characteristics of AVHRR-NDVI along latitudinal transects in northern Alaska. J. Veg. Sci. 2002, 13, 315-326.

5. Tieszen, L.L.; Reed, B.C.; Bliss, N.B.; Wylie, B.K.; DeJong, D.D. NDVI, $\mathrm{C}_{3}$ and $\mathrm{C}_{4}$ production, and distributions in Great Plains grassland land cover classes. Ecol. Appl. 1997, 7, 59-78.

6. Viereck, L.A.; Van Cleve, K.; Dyrness, C.T. Some aspects of vegetation and temperature relationships in the Alaska taiga. In The Potential Effects of Carbon Dioxide-Induced Climate Changes in Alaska; McBeath, J.H., Ed.; University of Alaska: Fairbanks, AL, USA, 1984; pp. 129-142.

7. White, A.B.; Kumar, P.; Tcheng, D. A data mining approach for understanding topographic control on climate-induced inter-annual vegetation variability over the United States. Remote Sens. Environ. 2005, 98, 1-20.

8. Viereck, L.A.; Dyrness, C.T.; Batten, A.R.; Wenzlick, K.J. The Alaskan Vegetation Classification; Report PNW-GTR-286; U.S. Forest Service: Portland, OR, USA, 1992.

9. Saxon, E.; Baker, B.; Hargrove, W.; Hoffman, F.; Zganjar, C. Mapping environments at risk under different global climate change scenarios. Ecol. Lett. 2005, 8, 53-60.

10. Bunn, A.G.; Goetz, S.J.; Fiske, G.J. Observed and predicted responses of plant growth to climate across Canada. Geophys. Res. Lett. 2005, 32, 1-4.

11. Dunn, A.L.; Barford, C.C.; Wofsy, S.C.; Goulden, M.L.; Daube, B.C. A long-term record of carbon exchange in a boreal black spruce forest: means, responses to interannual variability, and decadal trends. Glob. Chang. Biol. 2007, 13, 577-590.

12. Kang, S.; Kimball, J.S.; Running, S.W. Simulating effects of fire disturbance and climate change on boreal forest productivity and evapotranspiration. Sci. Total Envir. 2006, 362, 85-102.

13. Kimball, J.S.; Zhao, M.; McDonald, K.C.; Running, S.W. Satellite remote sensing of terrestrial net primary production for the pan-Arctic basin and Alaska. Mitig. Adapt. Strateg. Glob. Chang. 2006, 11, 783-804.

14. Rupp, T.S.; Chapin, F.S., III; Starfield, A.M. Response of subarctic vegetation to transient climatic change on the Seward Peninsula in north-west Alaska. Glob. Chang. Biol. 2000, 6, 541-555.

15. Asner, G.P.; Elmore, A.J.; Olander, L.P.; Martin, R.E.; Harris, T. Grazing systems, ecosystem responses, and global change. Ann. Rev. Environ. Resour. 2004, 29, 261-299.

16. Launchbaugh, K.; Brammer, B.; Brooks, M.L.; Bunting, S.; Clark, P.; Davison, J.; Fleming, M.; Kay, R.; Pellant, M.; Pyke, D.A.; Wylie, B.K. Interactions among Livestock Grazing, Vegetation Type, and Fire Behavior in the Murphy Wildland Fire Complex in Idaho and Nevada, July 2007; Report 2008-1214; U.S. Geological Survey: Reston, VA, USA, 2008. 
17. Dale, V.H.; Joyce, L.A.; McNulty, S.; Neilson, R.P.; Ayres, M.P.; Flannigan, M.D.; Hanson, P.J.; Irland, L.C.; Lugo, A.E.; Peterson, C.J.; Simberloff, D.; Swanson, F.J.; Stocks, B.J.; Wotton, B.M. Climate change and forest disturbances. BioScience 2001, 51, 723-734.

18. Boyte, S.P.; Wylie, B.K.; Gu, Y.; Major, D.J. Modeling future climate change effects on Big Sagebrush (Artemisia tridentata) and the ecosystem performance of five rangeland types in the Owyhee Uplands, USA. In USGS Climate Change Science Conference, Understanding the Past, Informing Decisions for the Future; U.S. Geological Survey: Denver, CO, USA, 2010.

19. Gu, Y.; Wylie, B.K. Detecting ecosystem performance anomalies in the upper Colorado River Basin-implication for land management. In Proceedings of DOI Conference on the Environment, Portland, OR, USA, April 2010.

20. Lauenroth, W.K.; Wade, A.A.; Williamson, M.A.; Ross, B.E.; Kumar, S.; Cariveau, D.P. Uncertainty in calculations of net primary production for grasslands. Ecosystems 2006, 9, 843-851.

21. Wylie, B.K.; Fosnight, E.A.; Gilmanov, T.G.; Frank, A.B.; Morgan, J.A.; Haferkamp, M.R.; Meyers, T.P. Adaptive data-driven models for estimating carbon fluxes in the Northern Great Plains. Remote Sens. Environ. 2007, 106, 399-413.

22. Zhang, L.; Wylie, B.K.; Tieszen, L.L. Anomalous ecosystem performance in boreal forests of the Yukon River Basin. In Proceedings of 2006 AGU Fall Meeting, San Francisco, CA, USA, December 2006; Abstract B21A-1009.

23. LANDFIRE Field Database; U.S. Department of Agriculture, Forest Service: Washiington, DC, USA. Available online: http://www.landfire.gov/ (accessed on 20 July 2010).

24. Homer, C.; Huang, C.; Yang, L.; Wylie, B.; Coan, M. Development of a 2001 National Land-Cover Database for the United States. Photogramm. Eng. Remote Sensing 2004, 70, 829-840.

25. Ji, L.; Wylie, B.K.; Ramachandran, B.; Jenkerson, C.B. A comparative analysis of three different MODIS NDVO data sets for Alaska and adjacent Canada. Can. J. Remote Sens. 2010, 36, S149-S167.

26. Swets, D.L.; Reed, B.C.; Rowland, J.R.; Marko, S.E. A weighted least-squares approach to temporal NDVI smoothing. In Proceedings of ASPRS Annual Conference, From Image to Information, Portland, OR, USA, 1999.

27. Jenkerson, C.B.; Maiersperger, T.K.; Schmidt, G.L. eMODIS: A User-Friendly Data Source; USGS Open-File Report 2010-1055; USGS: Sioux Falls, SD, USA, 2010; p. 10.

28. Calef, M.P.; McGuire, A.D.; Epstein, H.E.; Rupp, T.S.; Shugart, H.H. Analysis of vegetation distribution in Interior Alaska and sensitivity to climate change using a logistic regression approach. J. Biogeogr. 2005, 32, 863-878.

29. USGS LANDFIRE Data; USGS: Reston, VA, USA, 2009; Available online: http://landfire.cr.usgs.gov/viewer/ (accessed on 20 June 2009).

30. Cubist Software; RuleQuest Research Pty Ltd: NSW, Australia, 2009; Available online: http://www.rulequest.com (accessed on 18 July 2009).

(C) 2010 by the authors; licensee MDPI, Basel, Switzerland. This article is an Open Access article distributed under the terms and conditions of the Creative Commons Attribution license (http://creativecommons.org/licenses/by/3.0/). 